\title{
Artistic Swimming Helps the Intelligence Development
}

\author{
$1^{\text {st }}$ Danardani, Wasti \\ Postgraduate, State \\ University of Semarang \\ Semarang, Indonesia \\ wastidani@gmail.com
}

\author{
$2^{\text {nd }} K S$, Soegiyanto \\ Postgraduate, State \\ University of Semarang \\ Semarang, Indonesia \\ soegiyanto.ks@mail.unnes.ac.id
}

\author{
$3^{\text {nd }}$ Setijono, Hari \\ Postgraduate, State \\ University of Surabaya \\ Surabaya, Indonesia \\ harisetijono@yahoo.com
}

\author{
$4^{\text {nd }}$ Sulaiman, Sulaiman \\ Postgraduate, State \\ University of Semarang \\ Semarang, Indonesia \\ sulaiman@mail.unnes.ac.id
}

\begin{abstract}
Artistic swimming is a branch of sport which has an element of swimming, gymnastics, ballet, and dance. There are two kinds of training; land training and pool training. The training which is done on the land to increase physical capacity. Moreover, the training done in pool to improve skills. Appearance presented is very complex, so it involves more than one intelligence in a performance of artistic swimming. This study aims to see the form of intelligence contained in the artistic swimming. The object of this study is the national artistic, during eight months in Yogyakarta. The method of the study which has been implemented is the investigation of the phenomenon record that happened in the field and the confirmation toward the object and the informant about the phenomenon. The results showed in a display of artistic swimming can involve eight forms of intelligence as well. The involved intelligence in it is musical-rhythmic, visual-spatial, verbal-linguistic, logical-mathematical, bodily-kinaesthetic, interpersonal, intrapersonal, and naturalistic. Some intelligence capabilities can sometimes be performed simultaneously at a time. Benefits of the research shows that the activity of artistic swimming is not just a physical activity, but has the advantage of helping children develop multiple intelligences.
\end{abstract}

Keywords - multiple intelligences, artistic swimming

\section{INTRODUCTION}

Artistic swimming are not as well as known with swimming, diving, and water polo. But it is unique compared to other aquatic sports, under the auspices of PRSI (Persatuan Renang Seluruh Indonesia). In the appearance of the artistic swimming displays the physical abilities and beauty of movement as well as the harmony of music. This sport is less popular than other sports under PRSI. So the number of available human resources is still limited. This is evident from the national team members set up to face the 29th Seagames in Malaysia, only 10 athletes from four provinces of DKI Jakarta, West Java, DI Yogyakarta and South Sulawesi.

This becomes a challenge - for the team of coaches to form an excellent team. To prepare the excellent team required several factors supporting the development of athletes. Exercise factors consist of physical exercise, technique, tactics and psychology, a unit used to achieve peak performance in sports (Bompa and Haff, 2009). The exercises prepared by the trainers for the swimmers consist of the type 2 exercises that are the exercises on land and in the pools. Land training encompasses gymnastics, ballet, yoga, and physical conditioning. Meanwhile, water training consists of classic swimming, basic techniques of artistic swimming, and routine set. This sort of training can form the better physical ability of the artistic swimmers than another kinds of swimmer [5].

In the artistic swimming competition is categorized in three forms of appearance that is solo, duet and team. The three categories are become into 10 competition numbers: solo free routine (FR), solo technical routine (TR), duet FR, duet TR, duet mix FR, duet mix TR, FR team, TR team, combo team, and team highlights. They have different conditions between Of the 10 competition numbers. There are different interactions between swimmers at different competition numbers.

The differences not only about the number of swimmers but also seen from the duration of the performance of athletes and choreography provisions are displayed. On an artistic swimming number requires companion music, choreography and physical abilities. The choice of good 
companion music has a diverse tempo. Choreography is a series of movements consisting of basic movements and creative movements. For companion music and choreography have alignment. While the physical ability is the main capital in displaying the perfection of the display. The complexity of the artistic swimming not only focuses on physical ability but there is an art factor in its appearance.

The elements of contained in a artistic swimming, demanding a swimmer must have the ability and skills are diverse. In persuan of Piaget (Hergenhahn and Olson, 2008: 313-316) intelligence is a congenital innate trait that can change dynamically because of biological maturity and experience. While in the formation of knowledge Piaget introduces the scheme, assimilation and accommodation.

An individual can have seven different intelligences [8]. An individual not only has one kind of intelligence, will be able to have some intelligence in him. Intelligence is not solely about Classroom lessons, as people now know. Some intelligences can be developed simultaneously. Multiple intelligences are needed all the time from preparation to peak performance. The purpose of this study is to see the form of intelligence needed for artistic seater swimmers. The benefits of research show that seating activity is not physical

expression. But it has advantages in helping children develop multiple intelligences.

\section{METHOD}

The study has been conducted in the training centre of national team for the artistic swimming which is held in Yogyakarta during eight months. The participant is the artistic swimming athletes including female swimmers of 12-24 years old. The method of collecting the data of this study is narrative method which means that finding the data through the interview toward the informants by taking a note and recording the information. The information is gained from the stories which have been delivered by the informants, with no treatment involved from the researchers. The technique of collecting the data is done by collecting the documentation, while the narrative note is gained from the subject of the study and narrative interview from the researchers [4]. Moreover, the observation was completed through the direct observation toward the training process which is done in the training centre. The researchers did not give any treatment toward the object of the study, but only seek for the information. The information were gained from the interview of some informants on the occurrences. The informants consist of the swimmers and the trainers.

\section{RESULTS AND DISCUSSION}

\section{A. The terms competition of the artistic swimming}

In the artistic swimming competition is categorized in three forms of appearance that is solo, duet and team. The three categories are divided into 10 race numbers: solo free routine (FR), solo technical routine (TR), duet FR, duet TR, duet mix FR, duet mix TR, FR team, TR team, combo team, and team highlights. Of the 10 competitions numbers have different conditions between one and the other. The differences of these provisions can be seen in the table 1:

TABLE 1. DIFFERENCES CONDITIONS OF COMPETITION NUMBERS

\begin{tabular}{|c|c|c|c|}
\hline $\begin{array}{r}\text { C } \\
\text { ompn } \\
\text { umber } \\
s\end{array}$ & $\begin{array}{l}\text { Pa } \\
\text { rticipa } \\
\text { nts }\end{array}$ & $\begin{array}{r}\text { Du } \\
\text { ration }\end{array}$ & Conditions \\
\hline $\begin{array}{l}\text { So } \\
\text { lo FR }\end{array}$ & 1 & $\begin{array}{c}2^{\prime} \\
30 "\end{array}$ & $\begin{array}{l}\text { The series of motion is } \\
\text { composed of basic movement } \\
\text { techniques freely. Added } \\
\text { motion variations. }\end{array}$ \\
\hline $\begin{array}{l}\text { So } \\
\text { lo TR }\end{array}$ & 1 & $\begin{array}{c}2^{\prime} \\
00^{\prime \prime}\end{array}$ & $\begin{array}{l}\text { The series of motion is } \\
\text { composed of basic movement } \\
\text { techniques freely, including } 5 \\
\text { compulsory movements that } \\
\text { have been determined by FINA. } \\
\text { More variation movements can } \\
\text { be added to beautify the look. }\end{array}$ \\
\hline $\begin{array}{r}\mathrm{D} \\
\text { uet FR }\end{array}$ & 2 & $\begin{array}{c}3{ }^{\prime} \\
00 "\end{array}$ & $\begin{array}{l}\text { The series of motion is } \\
\text { composed of basic movement } \\
\text { techniques freely. Must make } \\
\text { moves with lifting technique. } \\
\text { Added motion variations }\end{array}$ \\
\hline $\begin{array}{r}\mathrm{D} \\
\text { uet TR }\end{array}$ & 2 & $\begin{array}{c}2^{\prime} \\
20^{\prime \prime}\end{array}$ & $\begin{array}{l}\text { The series of motion is } \\
\text { composed of basic movement } \\
\text { techniques freely, including } 5 \\
\text { compulsory movements that } \\
\text { have been determined by FINA. } \\
\text { Then must perform lifting } \\
\text { technique. More variation } \\
\text { movements can be added to } \\
\text { beautify the look. }\end{array}$ \\
\hline $\begin{array}{l}\text { D } \\
\text { uet } \\
\text { Mix } \\
\text { FR }\end{array}$ & 2 & $\begin{array}{c}3^{\prime} \\
00 "\end{array}$ & $\begin{array}{l}\text { The number of races is done } \\
\text { in pairs with different sex. The } \\
\text { series of motion is composed of } \\
\text { basic movement techniques } \\
\text { freely. Compulsory to make } \\
\text { movements with lifting } \\
\text { techniques. Added motion } \\
\text { variations }\end{array}$ \\
\hline $\begin{array}{l}\text { D } \\
\text { uet } \\
\text { Mix } \\
\text { TR }\end{array}$ & 2 & $\begin{array}{c}2^{\prime} \\
20^{\prime \prime}\end{array}$ & $\begin{array}{l}\text { The number of this race is } \\
\text { done in pairs with the different } \\
\text { sex. The series of motion is } \\
\text { composed of basic movement } \\
\text { techniques freely, including } 5 \\
\text { compulsory movements that }\end{array}$ \\
\hline
\end{tabular}




\begin{tabular}{|c|c|c|c|}
\hline & & & $\begin{array}{l}\text { have been determined by FINA. } \\
\text { Then must perform lifting } \\
\text { technique. More variation } \\
\text { movements can be added to } \\
\text { beautify the look. }\end{array}$ \\
\hline $\begin{array}{r}\text { Te } \\
\text { am FR }\end{array}$ & 4-8 & $\begin{array}{c}4^{\prime} \\
00^{\prime \prime}\end{array}$ & $\begin{array}{l}\text { The series of motion is } \\
\text { composed of basic movement } \\
\text { techniques freely. Must make } \\
\text { moves with lifting technique. } \\
\text { Added motion variations. }\end{array}$ \\
\hline $\begin{array}{r}\text { Te } \\
\text { am TR }\end{array}$ & 4-8 & 2" & $\begin{array}{l}\text { The series of motion is } \\
\text { composed of basic movement } \\
\text { techniques freely, including } 5 \\
\text { compulsory movements that } \\
\text { have been determined by FINA. } \\
\text { Then must perform lifting } \\
\text { technique. More variation } \\
\text { movements can be added to } \\
\text { beautify the look. }\end{array}$ \\
\hline $\begin{array}{l}\text { Te } \\
\text { am } \\
\text { Combi } \\
\text { nation }\end{array}$ & $10^{4-}$ & $\begin{array}{c}4^{\prime} \\
00 "\end{array}$ & $\begin{array}{l}\text { The series of motion is } \\
\text { composed of basic movement } \\
\text { techniques freely. Must make } \\
\text { moves with lifting technique. } \\
\text { Choreography variation is a } \\
\text { combination of solo, duet and } \\
\text { team. }\end{array}$ \\
\hline
\end{tabular}

Each of these competition numbers has different demands on the swimmer. Physically, the demands are the same for every swimmer for every competition number. The difference is seen in the psychological factors of swimmers. In this study know the favorite race number of the ten swimmers. Here's a table about the choice of competition numbers and the reasons they put forward.

\section{TABLE 2. FAVORIT COMPETITION NUMBERS}

\begin{tabular}{|c|c|}
\hline $\begin{array}{c}\text { Favorit } \\
\text { numbers of } \\
\text { competition }\end{array}$ & \multicolumn{1}{|c|}{ The reasons } \\
\hline Team FR & $\begin{array}{l}\text { The FR team is considered to be } \\
\text { more free in preparing the movement } \\
\text { because it can design a more varied and } \\
\text { attractive choreography. In addition they } \\
\text { chose this number because it did together } \\
\text { with many friends. The presence of } \\
\text { friends makes more daring to appear and } \\
\text { excited. }\end{array}$ \\
\hline $\begin{array}{c}\text { Team } \\
\text { Combination }\end{array}$ & $\begin{array}{l}\text { Their combination numbers judge } \\
\text { that this number is more colorful because } \\
\text { in a choreography it should display solo, } \\
\text { duet and team numbers in one view. They } \\
\text { also said that this team number has a } \\
\text { performance value that can attract a lot of } \\
\text { audience attention. }\end{array}$ \\
\hline Duet FR & $\begin{array}{l}\text { The reasons swimmer to choose duet } \\
\text { FR are revealed that felt no confidence to } \\
\text { perform solo. And less comfortable with } \\
\text { people. They claim that with both of them } \\
\text { they can build cooperation and more } \\
\text { easily achieve cohesiveness. }\end{array}$ \\
\hline $\begin{array}{c}\text { Feeling to be yourself, and being able } \\
\text { to present herself. Accept the risk of own } \\
\text { error without having to pay attention to } \\
\text { others. They do not want to be a burden } \\
\text { to the team because of a mistake made. }\end{array}$ \\
\hline The
\end{tabular}

Although swimmers have favorite numbers, not necessarily they will follow the race on that number. They will perform based on the coach's assessment of their abilities. So there is a learning process in the swimmers, including social learning. The learning process undertaken indirectly increases the ability of the swimmers, beyond the artistic pooling capabilities.

\section{B. Multiple intelligences in artistic swimming}

Changes that occur in individuals can be caused by the process of habituation. Implicit in habituation exemplary [15]. Some research deliberately habituates to get a new attitude on the individual. A research states that the formation of character is done through planned habituation through activities outside of learning [9]. Then provision of reinforcement as a business habituation of fair play in physical education [10]. From this research is clearly seen a deliberate treatment. The habituation done in a artistic swimming is not a separate, structured effort. But it is a mandatory requirement but must be met in order for their appearance to be good.

In observations made it was found that the artistic pool influenced and influenced individual intelligence. The intelligence found in the beautiful pool includes 8 multiple intelligences from Gardner $[2,8]$. Multiple intelligences are:

- Musical intelligence. The intelligence possessed by the individual in recognizing the type of sounds, recognizing the low-tone, recognize and enjoy the rhythm to be able to create and appreciate the tone. Music gives personality influences, different rhythms have different effects [12]. This intelligence is used by swimmers in making alignment of movement with music. Under the terms of the FINA assessment, music alignment with movement only contributes $10 \%$ of the value. There are two opinions of swimmers about the meaning of music. First they use music to lure count and form movements. The second opinion, they feel helpful in animating the movement with the presence of music. Manner in moving the body or motion with taste also has a weight of value. Intelligence gives the advantage to understand the tone and creates a harmony of motion [1]. 
- Kinesthetic Intelligence. Ability to control body movement in motion activity with special skills and specifik is the intelligence of body movement. Certainly the artistic swimming is influenced and influenced by kinesthetic intelligence. Motion skills are not only a form of sport but also in the form of dance. It is a key ingenuity factor to be a good swimmer. Kinesthetic intelligence has support for the development of other intelligences [14].

- Logic-mathematical intelligence. Individuals with mathematical logic intelligence have the sensitivity and ability to distinguish between shape and space, logically recognizing mathematical or numerical patterns, the ability to handle long chains of reasoning. Swimmers should be able to measure the speed of movement and speed of swimming. In some obligatory movements on the TR, it must be done at different speeds. And must be able to do an estimate the amount of movement angle both on hands and feet. In addition must be able to understand the amount of angle in the direction of movement.

- Linguistic intelligence (language). Sound sensitivity (sound / pronunciation), structure, meaning, word function, sensitivity to the word as a function of language and mastery of language, is the ability of imdvidu who have linguistic intelligence. In this study the swimmers were forced to understand English. Foreign trainers use English to deliver programs and evaluation exercises. In addition the swimmers must be able to understand the innate language of their respective regions. The environment that communication ability. Learn to express opinions to other friends. Redefine and construct linguistic intelligence through four-factor linguistic knowledge, pedagogical knowledge, valuing linguistic and cultural diversity, and linguistically responsive teaching behaviors [17].

- Visual / spatial intelligence. This intelligence is characterized by sensitively perceiving the spatial-visual world accurately and transforming initial perceptions. In this intelligence is used so that children can take into account the direction of motion together so as not to happen a collision. Movements also changes the shape of the position pattern. Imagining movement can support improving performance (Parikh; 2015).
- Interpersonal intelligence. The capacity to differentiate and respond to the environment matches the mood, temperament, motivation, and desires of others. The ability to control oneself. Used to interact with teammates. This process is built in and out of practice. Togetherness makes the swimmer learn to understand others. They are an inseparable unity. Interacting in a team causes an artistic swimming of attraction, because it always interacts with a partner or other team members. Results of research conducted on a hockey team, interpersonal intelligence has a role that is specific and specific in team sports [7].

- Intrapersonal intelligence. Individuals with the ability to understand their own feelings and the ability to distinguish emotions, knowing about the strengths and weaknesses themselves are individuals who have intra-personal intelligence. This intelligence can be self-strengthening. It develops in swimmers. This ability also serves to understand the attitude of others to themselves. Intra-personal intelligence was determined as the highest intelligence area [18].

- Naturalis intelligence. Expertise in the recognition and classification of the numerous species the flora and fauna of an individual's environment. This also includes sensitivity to other natural phenomena. this intelligence helps the swimmers punctuality, speed and energy used to perform lifting movements. They can apply physics theory in theirs performance. Naturalist intelligence will develop with direct experience as an effort to obtain information. besides this intelligence the same thing happens in spatial intelligence and konestetik

Artistic swim performance like a dance performance. Using the music accompaniment during the show, with beautiful movements, in harmony with music and costumes. Some swimmers reveal artistic swim is a fun activity. Concomitant with a study, represent are an activity involving multiple intelligence is a very fun activity. [13]. Other research, revealed that physical education can help the development of multiple intelligences [3]. Thus it can be said that artistic swimming is a physical activity that can help to improve intelligence in children. this activity involves 7 of 8 intelligences have Gardner in practice and appearance. So it is an ideal sport 
activity in stimulating the development of child intelligence.

\section{CONCLUSION}

Artistic Swimming is a sport with high complexity. The advantages of practicing this sport are not just body fitness. There are advantages obtained that 7 multiple intelligences can be simultaneously developed. Exercise can have an impact on the practice of multiple intelligences. So it can be said that between multiple intelligences and artistic swimming give a reciprocal effect. Not only artistic swimming conditions that require multiple intelligences but multiple intelligences can develop exactly with the excitement given during the beautiful swimming exercise.

\section{REFERENCE}

[1] Ambarwangi, Sri., And S . Suharto., "Reog As Means Of Students' Appreciation And Creation In Arts And Culture Based On The Local Wisdom" Journal Of Arts Research And Education 14 (1) (2014): 37-45 Available Online At Http://Journal.Unnes.Ac.Id/Nju/Index.Php/Harmonia

[2] Armstrong, Thomas., "Multiple intelligences in the classroom / Thomas Armstrong Association for Supervision and Curriculum Development. II." Title. LB1025.3.A76 2009 370.15'23 - dc22 2009000377K. 2005.

[3] Elizabeth, Asqui Luna Jessica., Cesar, León Sinche Julio., Roberto, Santillán Obregón Rodrigo., Altamirano, Humberto Rodrigo Santillán. Vite, Grace Amparo Obregón., and Morales, C. Santiago Calero., "Influence Of Multiple Intelligences Theory In Physical Education: Cases Study Influencia De La Teoría" De Las Inteligencias Múltiples En La Educación Física: Estudio De Casos. Revista Cubana de Investigaciones Biomédicas. 36(3) 1; 2017.

[4] Creswell, John. "Educational Research, Planning, Implementation, and Evaluation of Qualitative \& Quantitative Research" Edisi Kelima. Yogyakarta. Pustaka Pelajar. 2015.

[5] Dodigovic, Lucija., and Sindik, Josko., "Comparation Of Selected Health And Morphological Parameters Between Classic Swimming And Synchronized Swimming." Sport Scientific And Practical Aspect, 12(2): 5-9. 2015.

[6] Fan, Samantha P., Liberman, Zoe., Keysar, Boaz , and Katherine Kinzler, D. 2015. Article first published online: May 8, 2015; Issue published: July 1, 2015 Received: June 17, 2014; Accepted: February 03, 2015

[7] Friesen, Andrew P., Devonport, Tracey J., Lane, Andrew M., and Sellars, Christopher N., "Interpersonal Emotion Regulation: An Intervention Case Study With A Professional Ice Hockey Team. Athletic Insight" ISSN: 1947-6299 Volume 7, Number 2 Nova Science Publishers, Inc. 2015

[8] Gardner, Howard. "Multiple Intelligences." Interaksara, Batam. 2003

[9] Hidayat., Nur. "Implementation of Character Education Through Habitation at Pondok Pesantren Pabelan" Jurnal Pendidikan sekolah dasar Vo. 2, No. 1. 2016

[10] Herdiana., Deni. "Implementation of Supervision by Head of Agency In Efforts to Improve Employee Work
Discipline at the Regional Development Planning Board (Bappeda) Majalengka District" Cendikia Jurnal Ilmu Administrasi Negara. Vol. 9., no. 1. 2016

[11] Hajhashemi, Karim., Cook, James., Assoc, Nerina Caltabiano., Anderson, Neil., Seyed, Tabibzadeh Asadollah. "Multiple Intelligences, Motivations and Learning Experience Regarding Video-Assisted Subjects in a Rural University." International Journal of Instruction January $2018 \bullet$ Vol.11, No.1 e-ISSN: 1308-1470 • www.eiji.net p-ISSN: 1694-609X pp. 167-182, 2017.

[12] Krishnan, Vijaykumar., Karen A. Machleit And James J. Kellaris., Aurand, Timothy W. "Musical Intelligence: Explication, Measurement, And Implications For Consumer Behavior". Journal Of Consumer Marketing 31/4 (2014) 278-289 @ Emerald Group Publishing Limited [ISSN 0736-3761] [DOI 10.1108/JCM-01-2014-0843] Volume $31 \cdot$ Number $4 \cdot 2014 \cdot 278-289$

[13] Kumalasari, Lita., Hilmi, A Yusuf. and Didik Priyandoko. "The application of multiple intelligence approach to the learning of human circulatory system." Published under licence by IOP Publishing Ltd Journal of Physics: Conference Series, Volume 909, conference 12014.

[14] Pérez, Luis M.R., Nieto, Miriam P., Otero, Irene R., Amengual, Aixa R., Manzano, José A.N., "Relationships among multiple intelligences, motor performance and academic achievement in secondary school children." International Journal of Academic Research Part B;; 6(6) 1-9. 2014.

[15] Rochman, Abdul., "Guidance as the Base of the Cultivation of Adolescent Morals Values." Nadwa Jurnal Pendidikan Islam. Vol, Nomor 1. 2012

[16] Şener, Sabriye., Çokçalışkan, Ayten. "An Investigation between Multiple Intelligences and Learning Styles." Journal of Education and Training Studies Vol. 6, No. 2; February 2018

[17] Song, Kim H., and Simonsi, Jack D., "Beyond Gardner: A Pilot Case Study Assessing Teachers' Linguistic Intelligence University of Missouri-St. Louis" NYS TESOL JOURNAL Vol. 1, No. 1, January 2014 pg 66-81. 